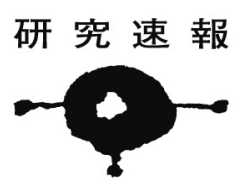

\title{
クランプ式電流センサと音響解析ソフトを用いた 誘発電位検査用電気刺激装置の出力点検
}

城屋敷健志* 元島 浩* 井関啓太* 谷口和久*

駒谷英基*1 安永親生 ${ }^{* 2}$ 川口浩太郎*,*3

\section{1. はじめに}

脳神経外科手術において近年, 術中操作に よる神経障害を回避する目的で術中誘発電位モ ニタリングが重要視されている ${ }^{1,2)}$. 術中誘発 電位モニタリング装置は電気刺激により, 感覚 神経や大脳皮質の運動野に電気刺激をおこなっ て, 大脳皮質感覚野の反応や筋の反応を計測す る.この誘発電位に用いる電気刺激は侵襲的で あり, 経頭蓋電気刺激に関しては $400 \mathrm{~V}$ 以上の 電気刺激を出力するため精度管理が重要とな り, 電気出力点検が必要となる.

医療機器の電気出力を計測する際の出力点検 は, 専用のチェッカー, もしくはオシロスコー プで計測が可能であるが, 出力点検に用いる装置 は高価であり, 専用のチェッカーに関しては単独 の機種にしか使用することが出来ないなどのデメ リットがある。このような現状を踏まえ, 電気出 力をおこなう医療機器(例えば電気入スなど) の出 力を計測する方法が考案されている ${ }^{3 \sim 5)}$. そこで 今回, 誘発電位用電気刺激装置の電気出力を簡 易に計測できる方法を考案した.

今回我々は電流および電圧計測のためにク ランプ式電流センサを使用した。 このクランプ 式電流センサの信号出力を何らかの方法で PC へ取り込み, 解析するために, PCのマイク入 力および音響解析ソフトに着目した。 近年のコ

* 済生会八幡総合病院臨床工学科

$\begin{array}{lll}* 1 & \text { 同 } & \text { 脳神経外科センター } \\ * 2 & \text { 同 } & \text { 腎センター } \\ * 3 & \text { 同 } & \text { 内科 }\end{array}$

ンピュータは音声入力用に高分解能の $\mathrm{A} / \mathrm{D}$ コ ンバータを備えており，実際にこのシステムを 用いて X 線計測の信号処理をおこなう試みがあ $ろ^{6)}$ 。また音響解析ソフトは汎用性があり，多 彩な解析機能が付いている.これらを利用して, 取り付けたクランプ式電流センサからの信号出 力をマイク入力から $\mathrm{AD}$ 変換し, 音響解析ソ フトで信号解析をおこなうことが今回の目的で ある。この方法を「クランプセンサを用いたオ シロスコープ代替による音響解析」(Acoustic analysis by using a clamp sensor alternative to the oscilloscope measurement = ASA 法）と名 付けた.この ASA 法によって, 従来使用して いたオシロスコープの代替方法として安価で簡 易的な装置で計測できるシステムを検討した。

\section{2. 方 法}

\section{1 ）クランプセンサの特性調査}

はじめに今回使用したクランプセンサ CTL6-S32-8F-CL（ユー・アール・ディー）の特性 調査をおこなった. 正弦波に対する周波数応 答は既知であるが7)，矩形波を計測する場合 で,さらに音響解析ソフト上で計測可能かは 未知である。計測は信号発生器 $\mathrm{AG}-203 \mathrm{~A}$ （KENWOOD）を用い peak-to-peak 值が 20mA の矩形波 $( \pm 10 \mathrm{~mA})$ を発生させ, ASA 法を用い, 音響解析ソフト Sound Engine free ${ }^{\circledR}$ (コードリ ウム)で取り込んだ時の周波数応答を計測した. 計測をおこなったクランプセンサには負荷抵抗 として $100 \Omega$ を取り付けている，なお，計測は 3 回おこない平均值をプロットした. 周波数応 


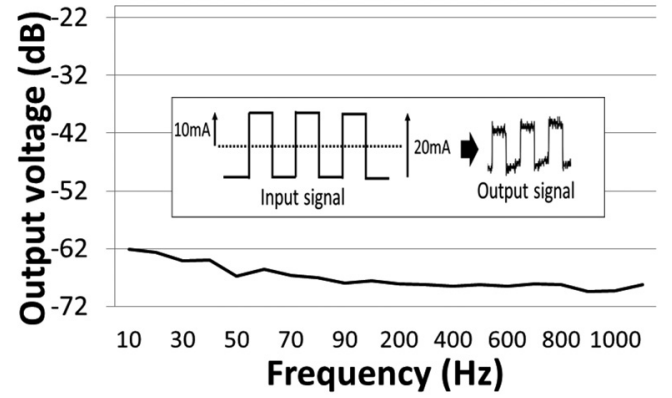

図 1 クランプセンサ CTL-6-S32-8F-CL の音 響解析ソフト上での周波数応答

答の結果を図 1 に示す。クランプセンサを用い て矩形波を音響解析ソフトで計測した場合, 波 形が変化した形状になるがピーク值の計測は可 能であった，正弦波を用いた場合，周波数応答 は $100 \mathrm{~Hz}$ から数 $\mathrm{kHz}$ までフラットで, $100 \mathrm{~Hz}$ 以下では出力が低下する波形となるが7), 矩形 波を与えた場合は図 1 のように $100 \mathrm{~Hz}$ 以下の 周波数領域では出力がわずかに上昇する結果と なった。このクランプセンサに取り付けた負荷 抵抗が $100 \Omega$ の場合, $50 \mathrm{~Hz}$ の周波数で良好な 直線性を示すため, 後述する実験システムでも $100 \Omega$ の負荷抵抗を取り付け, 出力計測をおこ なった。

2）実験システム

今回作成した実験システムを図 2 および図 3 に示す. 図 2 の実験システムは Neuropack ${ }^{\circledR}$ S 1 (日本光電) のメインユニット DC-940B の

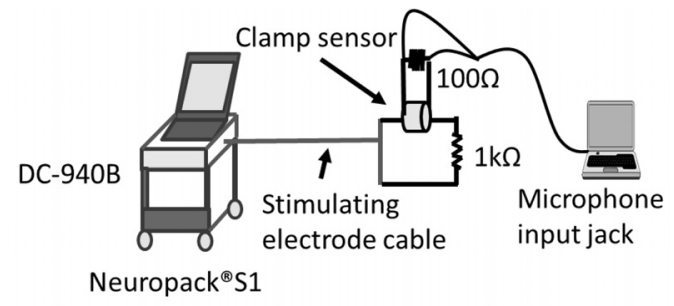

図2 DC-940B の実験システム

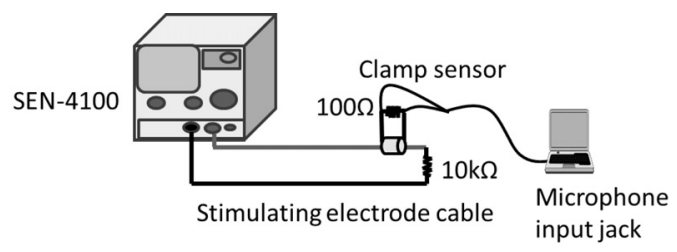

図3 SEN-4100 の実験システム
電気刺激出力部から刺激ケーブルを接続し, 先 端に $1 \mathrm{k} \Omega$ の負荷抵抗を取り付け，回路を作成 した．回路上にクランプ式電流センサを取り付 け，センサからの信号出力を $\mathrm{PC}$ のマイク入力 から取り込んだ。信号は音響解析ソフトを使用 し記録・解析した。 また, クランプ式電流セン サに取り付けた負荷抵抗は $100 \Omega$ とした.

次に運動誘発電位に使用される刺激装置 SEN-4100（日本光電）の実験システムを図 3 に示す．刺激ケーブルの先端に負荷抵抗 $10 \mathrm{k} \Omega$ を取り付け，回路を作成しクランプセンサを取 り付けた。 こちらもクランプセンサに取り付け た負荷抵抗は $100 \Omega$ とした.

この $2 つ の$ 実験システムを用いて出力計測実 験をおこなった。 なお，定期点検方法に則った 計測機器として，オシロスコープは BRINGO II DS-8824（IWATSU）を使用した.

\section{3）信号処理と解析}

双方の実験システムで取り込まれた信号は音 響解析ソフト Sound Engine free $\mathrm{B}^{\circledR}$ で計測・解 析をおこなった，実験の録音条件は，サンプリ ング周波数 $44.1 \mathrm{kHz}$ で $\mathrm{AD}$ 変換した。音響解 析ソフトで表示される利得 $\mathrm{G}$ は以下のように表 される。

$$
G(d B)=20 \log _{10} \frac{E_{0} x}{V_{0}}
$$

ここで, $\mathrm{V}_{0}$ は基準電圧, $\mathrm{E}_{0}$ はクランプセン サからの起電力, $\mathrm{x}$ は $\mathrm{PC}$ 内での増幅率である. 電流值はクランプセンサからの起電力と増幅 率の積であるため ASA 法で求められる電流值 $\mathrm{I}_{\mathrm{ASA}}$ は

$$
I_{A S A}=E_{0} x
$$

で表される。この計算式を用いて電流值を計 算し求めた。 また，負荷抵抗 $\mathrm{R} て ゙$ 構成される 回路において電圧值を計測する場合, 観測され る電気刺激波形を交流波形とみなすと, ASA 法で求められる電圧值 $\mathrm{V}_{\mathrm{ASA}}$ は以下の式となる.

$$
V_{A S A}=\sqrt{2} R I_{A S A}
$$

この式を用い, クランプセンサで計測される 電流值から電圧值を計算して求めた.

\section{4）DC-940B の電流出力計測}

図 2 の実験システムを用いて以下の実験を おこなった。 
(1)モニタリング使用時設定での計測

出力計測は $50 \mathrm{~Hz}$ の電気刺激出力で取り込ま れる信号特性を確認し, 設定は刺激頻度 $7 \mathrm{~Hz}$, 刺激持続時間 $0.2 \mathrm{~ms}$, 刺激電流值は $1 \mathrm{~mA}$ から $20 \mathrm{~mA}$ まで $1 \mathrm{~mA}$ 間隔で出力を計測した.

(2)定期点検方法での計測

次に取扱説明書に記載されてある定期点検方 法に則った計測方法で出力点検をおこなった. 設定は刺激頻度 $2 \mathrm{~Hz}$ ，刺激持続時間 $1 \mathrm{~ms}$, 刺 激電流值は $10 \mathrm{~mA}$ から $100 \mathrm{~mA}$ まで $10 \mathrm{~mA}$ 間隔 で出力を計測した。 また, ASA 法での計測值と オシロスコープ計測值を, 分散分析を用いて有 意差検定をおこなった。

(1)および(2)の実験では計測は 3 回おこない, 3 回の平均を求めた.

\section{5) SEN-4100 の電圧出力計測}

図 3 の実験システムを用い，以下の実験をお こなった.

(1)モニタリング使用時設定での計測

設定は刺激頻度 $500 \mathrm{~Hz}$ ，パルスは short train5 連発パルス, 刺激持続時間 $0.2 \mathrm{~ms}$, 刺激電圧は 300Vから 600V まで100V 間隔で計測した. なお, short train5 連発パルスの平均值を計算した。

(2)定期点検方法での計測

取扱説明書に記載されてある定期点検法に 則った計測方法で出力点検をおこなった．設定 は刺激頻度 $500 \mathrm{~Hz}$ ，パルスは short train5 連発 パルス，刺激持続時間は $0.2 \mathrm{~ms}$ とし， $500 \mathrm{~V}$ の 設定で ASA 法での計測值, オシロスコープ計 測值，表示電流值からの計算值を計測した。 ま た定期点検方法での設定で $300 \mathrm{~V}$ から 600V ま で $100 \mathrm{~V}$ 間隔で計測し，ASA 法での計測值と 表示電流值からの計算值, ASA 法での計測值 とオシロスコープ計測值を，分散分析を用いて それぞれ有意差検定をおこなった。

3）の実験と同様に，(1)よび(2)の実験では 計測を 3 回㧍こない, 3 回の平均を求めた.

6）スマートフォンおよびタブレットを用い た電気刺激波形の観測

より身近な機器で計測がおこなえることを 目的に，ハードウエアをノート PC からスマー トフォンおよびタブレットに変更して電気刺激 波形の観測が可能か調べた。スマートフォンは

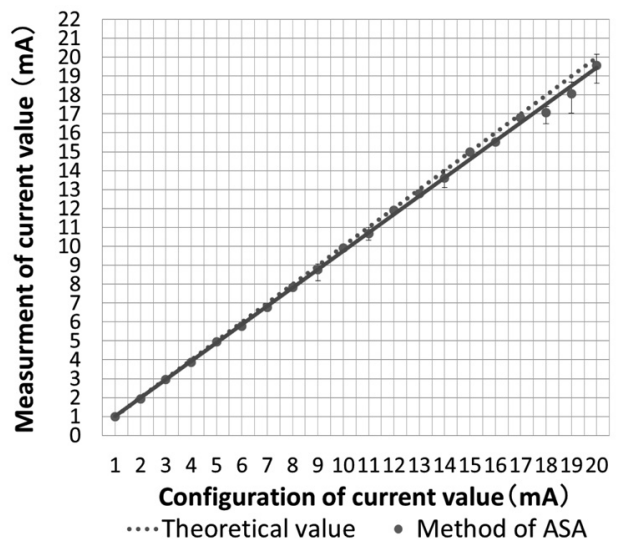

図4 DC-940B のモニタリング時設定での計測 結果

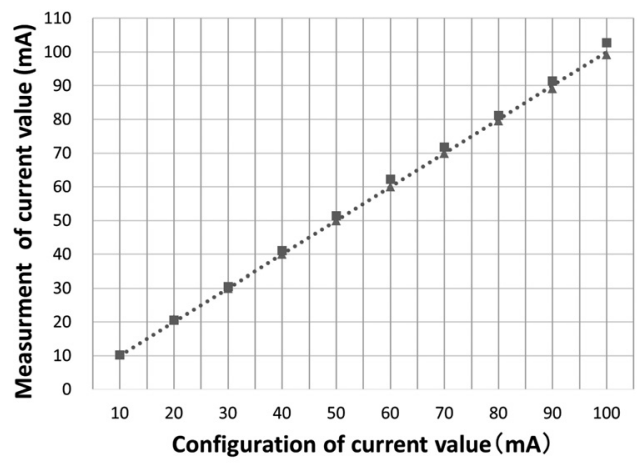

A Mesurement of oscilloscope $\|$ Method of ASA ... Theoretical value

図 5 DC-940B の定期点検法に則った方法での 計測結果

iPhone, タブレットは iPad を使用した。電気 刺激波形観測に使用したアプリは SignalScope （faberacoustical）を使用し，サンプリング周波 数 $44.1 \mathrm{kHz}$ で録音した。 今回，録音のためのデ バイスとして iPhone には Mobile In (LINE6), $\mathrm{iPad}$ にはUSB オーディオインターフェース Phono プリアンプ (BEHRINGER) を使用した. 図 1 の実験システムのように, 作成した回路上 にクランプセンサを取り付け，信号を取り込ん だ。観測した電気刺激波形は DC-940B からの 電気刺激出力で，刺激強度は $20 \mathrm{~mA}$ ，刺激持続 時間は $0.2 \mathrm{~ms}$ ，刺激間隔は $2 \mathrm{~ms}$ ，刺激パルスは short train5 連発パルスとした.

\section{3. 結 果}

1 ） DC-940B の電流出力計測 
(1)モニタリング使用時設定での計測

結果を図 4 に示す。縦軸は計測電流值，横軸 は設定電流值である, グラフの点線は設定電流 值であり，○はASA 法での計測值を示す。実 線は ASA 法での線形近似曲線である。結果は 良好な直線性を示し, 計測值の設定值からの平 均誤差は約 $3 \%$ であった。

(2)定期点検方法での計測

結果を図 5 に示す。縦軸は計測電流值，横軸 は設定電流值である，グラフの点線は設定電流 值であり， ははオシロスコープでの計測值,

は ASA 法での計測值である。こちらも良好な 直線性を示し，ASA 法と設定值の平均誤差は 約 $2 \%$ であり，オシロスコープ計測との差はな かった。

また有意差検定では，P 值が 0.9 以上であり， オシロスコープ計測と ASA 法での計測の有意 差は見られなかった。

\section{2）SEN-4100 の電圧出力計測}

(1)モニタリング使用時設定での計測

結果を図 6 に示す。縦軸は計測電圧值，横軸 は設定電圧值, グラフの黒色は理論值を示し, 灰色は計測結果を示す。計測の結果, 計測值と 理論值の平均誤差は約 $2 \%$ であった。許容範囲 は $5 \%$ 以内であるため, 結果は許容範囲内で あった

(2)定期点検方法での計測

結果を図 7 に示す。縦軸は計測電圧值，横 軸は設定電圧值, 棒グラフは左から, ASA 法, 表示電流值からの計測值，オシロスコープ計測 值の結果である。定期点検方法での許容範囲は 500V の設定で 410 から 490Vであるため，各 計測方法はすべて許容範囲内であった。

また有意差検定では，ASA 法での計測值と 表示電流值からの計測值は $\mathrm{P}$ 值が 0.88 以上, ASA 法の計測值とオシロスコープ計測值は P 值が 0.89 以上で有意差は見られなかった.

3）スマートフォンおよびタブレットを用い た電気刺激波形の観測

図 8 および図 9 に結果を示す。図 8 は iPhone を使用した電気刺激波形観測である。点線部に short train5 連発パルスが確認できる。眓 9 も 同様に, iPad を用いて波形の観測がおこなえた。

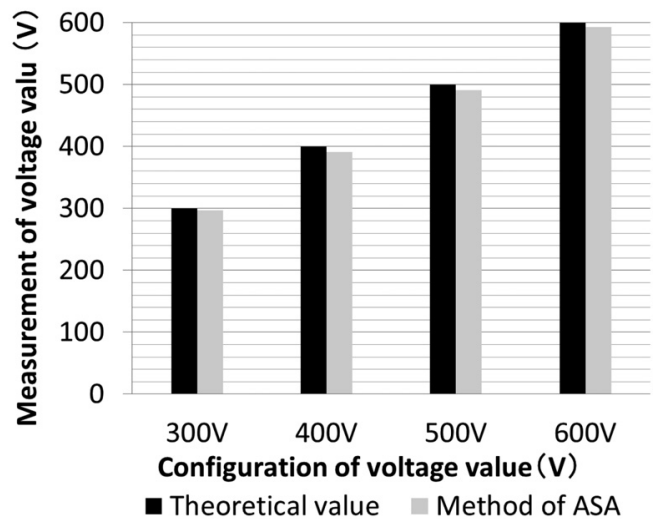

図6 SEN-4100 のモニタリング時設定での計 測結果

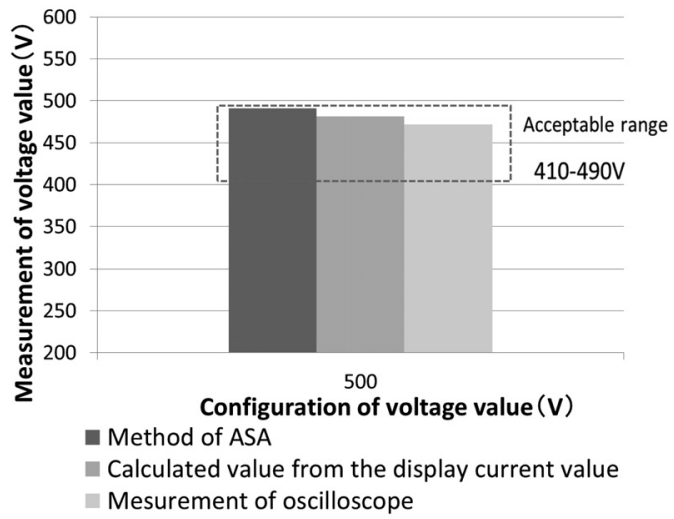

図7 SEN-4100 の定期点検に則った方法での 計測結果

\section{4. 考察}

DC-940B での電流出力計測の結果は良好な 直線性を示し，設定值およびオシロスコープ計 測との比較も良好な結果と言える. SEN-4100 の結果も各設定電圧での計測結果，定期点検方 法に則った各計測方法との比較でも良好な結果 と言える。しかしながら今回使用したクランプ センサの適正使用周波数は商用交流の周波数で ある $50 \mathrm{~Hz}$ から $60 \mathrm{~Hz}$ であり，これよりも低い， もしくは高い周波数では応答は悪くなる，実際 に計測をおこなうとランダムな波形の乱れが観 測されることがあった。このため，例えばパル ス計測がおこなえるクランプセンサや高周波用 クランプセンサに変更する必要があるが，計測 システムが大がかりになる事や，センサの価格 が高価となる場合がある。 


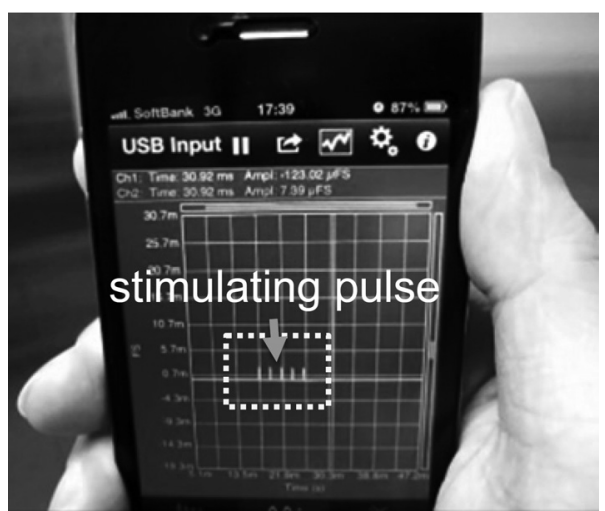

図8iPhoneによる電気刺激波形の確認

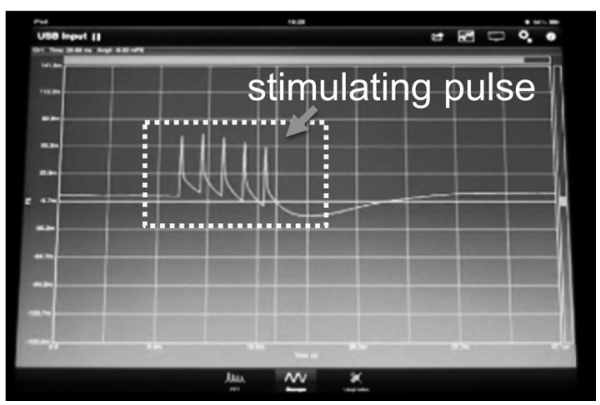

図9iPadによる電気刺激波形の確認

今回はノート PC を使用した計測をおこなった が, タブレットやスマートフォンでも電気刺激 波形観測がおこなえるため, 将来的には専用の アプリケーションを開発し計測を試みたい。実 際にこれらの汎用デバイスを用いた福祉機器や 生体音響計測装置の開発があるため ${ }^{8,9)}$, 普及面 を考慮すると, 誰しもが保有している機器, 安 価なセンサ, 簡単にダウンロード出来るアプリ ケーションによって. どこでも・誰でも簡単に 使用できるチェッカーが出来ると考える。 また, 他の電気出力医療機器 (除細動器やペースメー カー）でも計測が可能であると考えられ, 複数 の医療機器のチェッカーとして利用できるよう にセンサおよび信号処理に工夫が必要である。

\section{5. 結論}

今回の計測方法を用い, 誘発電位検査用電気 刺激装置の出力点検が可能であり, 他の医療機 器の出力点検に応用できる可能性が示唆された.

\section{謝辞}

技術的アドバイス, 実験装置の借用, 実験場 所の提供にご協力いただいた, 日本光電工業北 九州営業所, 九州工業大学和田研究室, 済生会 八幡総合病院手術部および脳神経外科センター に感謝します.

\section{文 献}

1) M.J. Malcharek, S. Ulkatan, V. Marinò et al, Intraoperative monitoring of carotid endarterectomy by transcranial motor evoked potential: A multicenter study of 600 patients, Clinical Neurophysiology, 2013, Vol.124, No.5, p.1025-1030.

2 ) 鈴木恭一, 佐々木達也, 松本正人ほか, 運動誘発 電位モニタリングを用いた脳動脈瘤手術, 脳卒 中の外科, 2006, Vol.34, p.101-108.

3 ) 岡野宏, 河村洋, 富樫昌之ほか 電気メステス夕 の開発と評価, 東京都立産業技術研究所研究報 告, 2004, Vol.7, p.79-80.

4) 木浦千夏子, 武田朴, 小野哲章, アナログ式熱変 換型電気メス出力チェッカの検討, 医療機器学 2011, Vol.81, No.2, p.125.

5 ) 堀純也, 森澤翠, 加藤知子ほか, 放射電磁波を利 用した電気メ久使用中点検法の検討 医療機器 学, 2012, Vol.82, No.1, p.25-30.

6 ) 中江保一, 河合潤, ノート型パソコンの音声入 力用 $\mathrm{A} / \mathrm{D}$ コンバータを用いたX線計測, X線分 析の進歩, 2010, Vol.41, p.157-163.

7 ) 株式会社ユー・アール・ディー “極小型ク ランプ式交流電流センサ（ $\phi 6 / 15$ Arms $) ”$ http://www.u-rd.com/products/CTL-6-S328F-CL_tab1.html\#detail_tab

8 ) 宮田充, 和田親宗, 飯沼正博, 携帯情報端末を用 いた聴覚障害者向けX線検査支援システムの有 用性について, ヒューマンインタフェースシン ポジウム論文集, 2012, Vol.2012, p.297-30.

9 ) 中野博, 石松明子, 本村知華子, スマートフォ ンによる肺音計測の試み, 薬理と臨床, 2013, Vol.23, No.1, p.29-31. 